\title{
Blockade of Dopamine D4 Receptors Attenuates Reinstatement of Extinguished Nicotine-Seeking Behavior in Rats
}

\author{
Yijin Yan', Abhiram Pushparaj', Yann Le Strat', Islam Gamaleddin', Chanel Barnes ${ }^{2}$, Zuzana Justinova ${ }^{2,3}$, \\ Steven R Goldberg ${ }^{2}$ and Bernard Le Foll*, I,4 \\ 'Translational Addiction Research Laboratory, Centre for Addiction and Mental Health Addiction (CAMH), University of Toronto, Toronto, ON, \\ Canada; ${ }^{2}$ Preclinical Pharmacology Section, Behavioral Neuroscience Research Branch, Intramural Research Program, National Institute on Drug \\ Abuse, National Institutes of Health, Department of Health and Human Services, Baltimore, MD, USA; ${ }^{3}$ Department of Psychiatry, Maryland \\ Psychiatric Research Centre, University of Maryland School of Medicine, Baltimore, MD, USA; ${ }^{4}$ Departments of Family and Community Medicine, \\ Pharmacology, Psychiatry, Institute of Medical Sciences, University of Toronto, Toronto, Canada
}

\begin{abstract}
Since cloning of the dopamine receptor D4 (DRD4), its role in the brain has remained unclear. It has been reported that polymorphism of the DRD4 gene in humans is associated with reactivity to cues related to tobacco smoking. However, the role of DRD4 in animal models of nicotine addiction has seldom been explored. In our study, male Long-Evans rats learned to intravenously self-administer nicotine under a fixed-ratio (FR) schedule of reinforcement. Effects of the selective DRD4 antagonist L-745,870 were evaluated on nicotine selfadministration behavior and on reinstatement of extinguished nicotine-seeking behavior induced by nicotine-associated cues or by priming injections of nicotine. L-745,870 was also tested on reinstatement of extinguished food-seeking behavior as a control. In addition, the selective DRD4 agonist PD 168,077 was tested for its ability to reinstate extinguished nicotine-seeking behavior. Finally, $\mathrm{L}-745,870$ was tested in Sprague Dawley rats trained to discriminate administration of $0.4 \mathrm{mg} / \mathrm{kg}$ nicotine from vehicle under an FR schedule of food delivery. L-745,870 significantly attenuated reinstatement of nicotine-seeking induced by both nicotine-associated cues and nicotine priming. In contrast, L-745,870 did not affect established nicotine self-administration behavior or reinstatement of foodseeking behavior induced by food cues or food priming. L-745,870 did not produce nicotine-like discriminative-stimulus effects and did not alter discriminative-stimulus effects of nicotine. PD 168,077 did not reinstate extinguished nicotine-seeking behavior. As DRD4 blockade by L-745,870 selectively attenuated both cue- and nicotine-induced reinstatement of nicotine-seeking behavior, without affecting cue- or food-induced reinstatement of food-seeking behavior, DRD4 antagonists are potential therapeutic agents against tobacco smoking relapse. Neuropsychopharmacology (2012) 37, 685-696; doi: I0.1038/npp.20II.245; published online 26 October 20I I
\end{abstract}

Keywords: dopamine receptor D4; receptor antagonist; nicotine self-administration; reinstatement of nicotine-seeking behavior; tobacco smoking; relapse

\section{INTRODUCTION}

Nicotine is considered the major psychoactive component of tobacco leading to smoking addiction, a chronic brain disorder with the specific characteristics of difficulty in stopping smoking, highly frequent relapse after abstinence, and high comorbidity with other mental disorders (Brady and Sinha, 2005; Dalack et al, 1998; DiFranza and Ursprung, 2010; Hitsman et al, 2009; Le Foll and Goldberg, 2006;

*Correspondence: Dr B Le Foll, Translational Addiction Research Laboratory, Centre for Addiction and Mental Health Addiction (CAMH), University of Toronto, 33 Russell Street, Toronto, ON M5S 2SI Canada, Tel: +416535850I extension 4772, Fax: + 416 595 6922, E-mail: bernard_lefoll@camh.net

Received 10 March 2011; revised 16 August 2011; accepted 13 September 201 I
Morisano et al, 2009; Ziedonis et al, 2008). Nicotine has been reported to support the acquisition, maintenance, and reinstatement of nicotine-seeking behavior induced by the presentation of nicotine-associated cues or by a priming injection of nicotine in rodents, dogs, non-human primates, and humans (Corrigall, 1999; Corrigall and Coen, 1989; Donny et al, 1995; Goldberg et al, 1981; Le Foll et al, 2007; Liu et al, 2006; Risner and Goldberg, 1983; Rose and Corrigall, 1997; Shaham et al, 1997; Sofuoglu et al, 2007). The reinforcing effects of nicotine are primarily due to activation of mesoaccumbal dopamine system (Corrigall and Coen, 1991; Corrigall et al, 1992; Di Chiara, 2000; Laviolette and van der Kooy, 2004; Liu et al, 2010; Mansvelder and McGehee, 2000; Picciotto, 2003; Pidoplichko et al, 1997; Pierce and Kumaresan, 2006; Self, 2004; Wise, 2004), although emerging evidence suggests that other 
neurotransmitter systems are involved as well. Among the components of the mesoaccumbal dopamine system, dopamine receptors are classified into two super families: D1-like (D1 and D5) and D2-like (D2, D3 and D4), based on their amino-acid sequence homology and modulation of intracellular adenyl cyclase activity. Different subtypes of dopamine receptors have substantially different expression levels in distinct neuronal populations of the brain, thereby having fundamentally different roles in the development of substance dependence/addiction and relapse (Andreoli et al, 2003; Corrigall and Coen, 1991; Di Chiara, 2000; Haile and Kosten, 2001; Khaled et al, 2010; Liu et al, 2010; Ross et al, 2007). Among these dopamine receptors, the role of the dopamine receptor D4 (DRD4) in the development of nicotine dependence and relapse remains unclear (see Le Foll et al, 2009 for review).

It has been reported that chromosome $11 \mathrm{p}$, which includes the DRD4 locus, is associated with increased susceptibility to cigarette smoking (Gelernter et al, 2004). In humans, the DRD4 gene is highly polymorphic with a variable number of tandem repeats (VNTRs) in exon III (in particular, the presence or absence of the 7-repeat ('long') allele) and a single-nucleotide polymorphism in the promoter region $(\mathrm{C}-521 \mathrm{~T})$, with both being associated with variation in the expression of DRD4, decreased ligand binding, and attenuation of cyclic adenosine monophosphate (cAMP) formation (Asghari et al, 1994, 1995; Cohen et al, 1992). In depressed smokers, homozygous for the short alleles of the DRD4 gene, smoking practices related to self-medication (ie. smoking to increase arousal or decrease negative affect) were significantly higher when compared with smokers heterozygous or homozygous for the long alleles (Lerman et al, 1998). Recently, these two polymorphisms of the DRD4 gene have been linked to chronic alcoholism, tobacco smoking, opioid dependence, impulsivity, novelty-seeking behavior, and attention-deficit hyperactivity disorder (Chien et al, 2010; Ebstein et al, 1996; George et al, 1993; Ho et al, 2008; Kotler et al, 1997; Li et al, 2000; Luciano et al, 2004). In addition, the VNTR polymorphism of the DRD4 gene has been correlated with smoking and cocaine cue reactivity, as well as alcohol- and heroin-craving behavior (Hutchison et al, 2002a, b, 2003, 2006; McClernon et al, 2007; Munafo and Johnstone, 2008; Shao et al, 2006).

The ability of DRD4 antagonists to reverse the rewarding effects of nicotine that are primarily responsible for tobacco dependence has seldom been explored with animal models. Previously, DRD4 antagonists have been reported to attenuate the discriminative-stimulus effects of cocaine and methamphetamine (Ukai and Mitsunaga, 2005; Yan et al, 2004, 2006), and to attenuate morphine-induced withdrawal signs precipitated by naloxone (Mamiya et al, 2004). Using an intravenous (i.v.) cocaine self-administration model, it was noted that pretreatment with the dopamine D3/D4 receptor antagonist L-745,829 or the selective DRD4 antagonist L-745,870 does not affect cocaine self-administration in rats (Caine et al, 2002). In this study, we examined the effects of the selective DRD4 antagonist (L-745,870) on established nicotine self-administration behavior and on reinstatement of extinguished nicotineseeking behavior induced by either nicotine-associated cues or by a priming injection of nicotine in rats. We also tested the selective DRD4 agonist (PD 168,077) for its ability to reinstate extinguished nicotine-seeking behavior. Finally, to evaluate whether D4 receptors were affecting reinstatement of nicotine seeking by altering an animal's ability to discriminate the effects of nicotine, we examined the effects of L-745,870 in a classic two-lever nicotine discrimination procedure.

\section{MATERIALS AND METHODS}

\section{Subjects and Drugs}

Male Long-Evans rats (Charles River, Lachine, PQ, Canada) were used for all nicotine and food self-administration experiments, whereas male Sprague Dawley rats (Charles River, Wilmington, MA, USA) were used for discrimination studies to be consistent with previous studies (Le Foll and Goldberg, 2004, 2005; Le Foll et al, 2008). Animals were initially group housed in a humidity- and temperaturecontrolled $\left(21-22^{\circ} \mathrm{C}\right)$ vivarium on a 12 -h reversed light/ dark cycle with access to ad libitum water and food. After a week of habituation to the colony room, animals were singularly housed and diet restricted ( $\sim 20 \mathrm{~g} /$ day $)$ throughout the experiments. All experimental procedures described in this study were carried out in compliance with the guidelines of the Canadian Council on Animal Care and/or the guidelines of the Animal Care and Use Committee of the National Institute on Drug Abuse Intramural Research Program.

$(-)$ Nicotine hydrogen tartrate (Sigma-Aldrich, St Louis, MO, USA) was dissolved in saline and the $\mathrm{pH}$ of solution was adjusted to $7.0 \pm 0.2$. Nicotine solution was freshly prepared and filtered through a $0.22-\mathrm{mm}$ syringe filter (Fisher Scientific, Pittsburgh, PA, USA) to minimize the risk of infection. All nicotine doses are described as free base concentrations. Nicotine was administered i.v. in a volume of $100 \mu \mathrm{l} / \mathrm{kg}$ per infusion or subcutaneously (s.c.) in a volume of $1 \mathrm{ml} / \mathrm{kg}$.

The selective DRD4 antagonist L-745,870 (3-[4-(4-chlorophenyl)piperazin-1-yl]methyl-1 $H$-pyrrolo[2,3-b]pyridine) hydrochloride (Sigma-Aldrich) was reported to have high selectivity for DRD4, >2000-fold compared with other dopamine receptor subtypes and a low-moderate affinity $($ IC50 $<300 \mathrm{nM})$ for non-dopaminergic receptors (Patel et al, 1997). L-745,870 was dissolved in 100\% alcohol (final concentration $5 \% \mathrm{v}: \mathrm{v}$ ) by a Shaker and/or sonication, and then polyethylene glycol 400 was added and mixed again by a Shaker (final concentration $10 \% \mathrm{v}: \mathrm{v}$ ), and, finally, sterile water was added for a final concentration of $1.5 \mathrm{mg} / \mathrm{ml}$ L-745,870 (free base). The lower doses of L-745,870 were diluted from the $1.5 \mathrm{mg} / \mathrm{ml}$ concentration with vehicle solution (sterile water containing 5\% alcohol and $10 \%$ polyethylene glycol 400). L-745,870 solution was freshly prepared and administered $30 \mathrm{~min}$ before all tests (ie, $30 \mathrm{~min}$ before animals were placed in chambers) in a volume of $1 \mathrm{ml} / \mathrm{kg}$. Selection of L-745,870 doses $(0.1-3.0 \mathrm{mg} /$ $\mathrm{kg})$, pretreatment time, volume of injection $(2 \mathrm{ml} / \mathrm{kg})$, and route of administration were based on previous reports (Caine et al, 2002; Yan et al, 2004, 2006).

The selective DRD4 agonist PD 168,077 ( $N$-([4-(2-cyanophenyl)piperazin-1-yl]methyl)-3-methylbenzamide) maleate (Tocris, Ellisville, MO, USA) was dissolved in saline to a 
final concentration of $3.0 \mathrm{mg} / \mathrm{ml}$ of PD 168,077 (free base) (Glase et al, 1997). Lower doses were prepared by diluting with saline solution. PD 168,077 solution was also freshly prepared and administered $30 \mathrm{~min}$ before all tests in a volume of $1 \mathrm{ml} / \mathrm{kg}$.

\section{Apparatus for Nicotine Self-Administration, Food Self-Administration, and Nicotine Discrimination}

All experiments were conducted in standard operant conditioning chambers located inside sound-attenuating, ventilated cubicles (Med Associates, St Albans, VT). Each chamber was equipped with two response levers on a panel on one side of the chamber, with a $28-\mathrm{V}$ white cue light above each lever, and with a white chamber light mounted on the ceiling on the opposite side of the chamber. There was a recessed food receptacle between the two levers, which was used for experiments involving food selfadministration and reinstatement of food-seeking behavior and nicotine discrimination, and for the initial food training procedure before self-administration. I.v. nicotine infusions were delivered using a syringe pump (PHM-100, Med Associates) located outside each cubicle.

\section{Food Training Procedure before Catheterization}

After a 24-h deprivation period, rats were subjected to 1-h daily sessions of lever-press training reinforced by food pellets (45 mg) under a fixed-ratio 1 (FR1) schedule for 5 days. During these sessions, the chamber light was on, but the lever light was unavailable throughout each 1-h session. Assignment of the active lever was counterbalanced across animals, so that in half of the rats, the right lever was active (produced food delivery) and vice versa. Responses on the inactive lever had no programmed consequences. Once assigned, the active lever was fixed for each animal throughout all experiments. These rats were food restricted for the remainder of the experiment but had ad libitum access to water.

\section{Surgical Procedures for Catheterization into the Jugular Vein}

After food training, rats were surgically implanted with catheters into the right external jugular vein. Surgery was performed under anesthesia induced by xylazine $(10 \mathrm{mg} / \mathrm{kg})$ and ketamine hydrochloride $(75 \mathrm{mg} / \mathrm{kg})$. Once anesthetized, marcaine was infused into the incision sites and buprenorphine $(0.03 \mathrm{mg} / \mathrm{kg})$ was administered s.c. to provide analgesia. Although surgeries were performed using aseptic techniques, penicillin was administrated s.c. in a single dose of 30000 Units. The catheter consisted of silastic tubing joined to polyethylene tubing, which terminated in a threaded nylon connector with an attached piece of surgical mesh. The silastic end was inserted into the jugular vein, and the catheter passed s.c. to the dorsal surface between the scapulae where it exited. After surgery, animals recovered from anesthesia on a heating pad, and a s.c. infusion of $\sim 10 \mathrm{ml} / \mathrm{kg}$ sterile isotonic saline was administered for fluid replacement. Animals then had a 1-week recovery period before commencement of experimental procedures. After recovery from surgery, the catheter was flushed daily with saline containing heparin $(0.1 \mathrm{ml}, 30 \mathrm{Units} / \mathrm{ml})$, and catheter patency was verified by administration of methohexital at the completion of nicotine self-administration experiments. In cases of catheter failure, animals were not re-catheterized but were excluded from the study.

\section{I.v. Nicotine Self-Administration Procedure}

Daily 1-h sessions of nicotine self-administration were conducted Monday through Friday. Acquisition of nicotine self-administration occurred at a dose of $0.03 \mathrm{mg} / \mathrm{kg}$ per infusion and an infusion volume of $0.1 \mathrm{ml} / \mathrm{kg}$. Duration of each nicotine infusion was $\sim 1 \mathrm{~s}$, but was adjusted to accommodate inter-animal or between-session differences in body weight. Initially, each active lever press resulted in an infusion of nicotine (FR1). Nicotine delivery was signaled by illumination of the light above the active lever and turning off of the chamber light. These cues continued for 60 seconds (timeout period), during which time lever presses were recorded but had no programmed consequence. Lever requirements were gradually increased to a final value of 5 (FR1 for 5 days, FR2 for 3 days, and FR 5 for at least 12 days). Under an FR5 schedule of reinforcement, rats were considered to have acquired stable nicotine selfadministration according to the following criteria: they pressed the active lever more than twice the number of times they pressed the inactive lever, and received a minimum of 10 infusions per 1 -h session with $<20 \%$ variation in the number of infusions earned per session over three consecutive sessions.

Experiment 1: Effects of the DRD4 Antagonist L-745,870 on Nicotine-Taking and Cue-Induced Reinstatement of Nicotine-Seeking Behavior

Animals were first trained to self-administer nicotine at a dose of $0.03 \mathrm{mg} / \mathrm{kg}$ per infusion, as described in detail above. Once nicotine self-administration behavior was stable under an FR5 schedule, testing of the effects of L-745,870 on nicotine-taking behavior was carried out according to within-subjects Latin square design. Doses of L-745,870 were: 0 (vehicle), $0.1,0.3,1.0$, and $3.0 \mathrm{mg} / \mathrm{kg}$ and L-745,870 or vehicle was administered intraperitoneally (i.p.) $30 \mathrm{~min}$ before animals were placed into the chambers. Test sessions were separated by three or more sessions of nicotine self-administration, which were conducted daily until animals met the above criteria for stable selfadministration over two consecutive sessions.

Once this testing with L-745,870 was completed, the same group of animals was again subjected to three or more sessions of nicotine self-administration, which were conducted daily until animals met the criteria for stable selfadministration over two consecutive sessions. Daily 1-h sessions of extinction training were then conducted, during which the chamber light was on throughout the whole session, but neither nicotine infusion nor lever lights were available. Responses on either the active or inactive lever had no programmed consequences but were recorded. The criterion for extinction was three consecutive daily sessions with $<20$ active lever responses or with active lever responses that were $<20 \%$ of the average for active lever 
responses that occurred during the last 5 days of nicotine self-administration.

Once animals achieved the criteria for extinction training, testing of effects of L-745,870 on cue-induced reinstatement of nicotine-seeking behavior was conducted according to a within-subjects Latin square design. Pretreatment time and doses of L-745,870 were as the same as described above. Conditions for test sessions involving cue-induced reinstatement were identical to those involving nicotine selfadministration, except that (1) a single presentation of the visual cue (active lever light on and chamber light off for $10 \mathrm{~s}$ ) was non-contingently delivered immediately at the start of the session and (2) responses on the active lever (under an FR5 schedule) resulted in contingent presentation of the cues (active lever light on and chamber light off for $10 \mathrm{~s}$ ) without nicotine infusion. All responding on the active lever was recorded, including those occurring due to 10 -s cue presentations, and served as the measure of reinstatement. Responses on the inactive lever had no programmed consequences but were recorded. Test days were separated by three or more daily $1-\mathrm{h}$ sessions of extinction training until animals met the above criteria for extinction over two consecutive sessions.

\section{Experiment 2: Effects of L-745,870 on Nicotine-Primed Reinstatement of Nicotine-Seeking Behavior}

A separate group of naive rats was first trained to selfadminister nicotine at $0.03 \mathrm{mg} / \mathrm{kg}$ per infusion as described in Experiment 1. Once nicotine self-administration behavior was stable under an FR5 schedule, rats were then exposed to daily 1-h sessions of extinction training until they met the criteria for extinction described above.

Testing for the effects of L-745,870 on nicotine-primed reinstatement of nicotine-seeking behavior was carried out according to a within-subjects Latin square design. The pretreatment time and doses of L-745,870 were the same as in Experiment 1. A priming injection of nicotine $(0.15 \mathrm{mg} /$ $1 \mathrm{ml}$ per $\mathrm{kg}$ ) was administered s.c. $10 \mathrm{~min}$ before the start of the test session. Nicotine-primed reinstatement tests were conducted under conditions identical to those of extinction training. During test sessions, neither nicotine infusion nor nicotine-associated cues (lever lights) was available. Responses on the active or inactive lever had no programmed consequences but were recorded. Test days were separated by three or more three daily 1 -h sessions of extinction training until the above criteria for extinction were met over two consecutive sessions.

\section{Experiment 3: Effects of L-745,870 on Reinstatement of Food-Seeking Behavior Induced by Food Priming or Food-Associated Cues}

Another group of naive rats learned to self-administer food (45 mg pellets) under a FR schedule identical to that used for nicotine self-administration. In brief, rats were initially subjected to daily 1 -h sessions of lever-press training under an FR1 schedule for 5 days, then FR2 for 3 days, and finally FR5 for 12 days, during which time animals developed stable food-maintained operant self-administration behavior.

Rats were then subjected to extinction training, as described above. Once the criteria for extinction were met, the effects of different doses of L-745,870 on food-primed reinstatement of food-seeking behavior were tested according to a within-subjects Latin square design. Pretreatment time and doses of L-745,870 were the same as in Experiment 1. Priming with food was conducted as follows: three food pellets were non-contingently delivered to the recessed food receptacle between the two levers during the first $3 \mathrm{~min}$ of the test sessions. Food-primed reinstatement tests were conducted under conditions identical to those of extinction training, with neither food delivery nor food-associated cues (lever lights) available during the session. Responses on the active or inactive lever had no programmed consequences but were recorded. Test days were separated by three or more daily $1-\mathrm{h}$ sessions of extinction until the above criteria for extinction over two consecutive sessions were met.

After completion of the above testing, rats were exposed to food self-administration once again until they showed stable operant behavior. Once behavior was stable, animals were again subjected to extinction training until criteria for extinction were met. Testing of the effects of L-745,870 on cue-induced reinstatement of food-seeking behavior was then conducted according to a within-subjects Latin square design. Pretreatment time and doses of L-745,870 were as same as described above. Conditions for test sessions studying reinstatement by food-associated cues were identical to those for studying reinstatement by nicotineassociated cues described above. In brief, cue-induced reinstatement tests were conducted under conditions identical to those of food-maintained operant training, except that (1) a single presentation of the visual cue (active lever light on and chamber light off for $10 \mathrm{~s}$ ) was delivered response independently immediately at the start of the session and (2) responses on the active lever (under an FR5 schedule) resulted in contingent presentation of the cues (active lever light on and chamber light off for $10 \mathrm{~s}$ ) without food delivery. Responses on the inactive lever had no programmed consequences but were recorded. Each test day was followed by $\geqslant 3$ days with 1 -h extinction sessions until rats met the criteria for extinction over two consecutive sessions.

\section{Experiment 4: Effects of Selective DRD4 Agonist PD 168,077 on Nicotine- and Food-Seeking Behavior during Extinction}

A group of naive rats was first trained to self-administer nicotine at $0.03 \mathrm{mg} / \mathrm{kg}$ per infusion and exposed to extinction training as described above. Testing of the effects of PD 168,077 on nicotine-seeking behavior during extinction was carried out according to a within-subjects Latin square design. PD $168,077(0.03,0.3$, and $3.0 / \mathrm{kg})$ was administered i.p. $30 \mathrm{~min}$ before start of the test sessions. Conditions during test sessions were identical to those during extinction training sessions.

A separate group of rats was trained to respond to food and subsequently exposed to extinction training. Once extinction criteria were met, they were tested with PD 168,077 for reinstatement of extinguished food-seeking behavior in a similar manner to that of their nicotinetrained counterparts. 
Experiment 5: Effects of Selective DRD4 Antagonist L-745,870 on Nicotine Discrimination

Establishment of nicotine discrimination in male Sprague Dawley rats. Training of the initial food self-administration behavior for these experiments was similar to that reported previously (Caine et al, 2002; Yan et al, 2004, 2006). After this, rats were trained under a discrete-trial schedule of food pellet delivery to respond on one lever when an injection of a training dose of $0.4 \mathrm{mg} / \mathrm{kg}$ nicotine was administered s.c. $10 \mathrm{~min}$ before the session and on the other lever when an injection of $1 \mathrm{ml} / \mathrm{kg}$ of saline vehicle was administered s.c. $10 \mathrm{~min}$ before the session. At the start of the session, a white house light was turned on, and in its presence, rats responded to food under a FR10 schedule. The completion of 10 consecutive responses on the appropriate lever delivered a $45 \mathrm{mg}$ food pellet and initiated a 45-s time out during which lever-press responses were recorded but had no programmed consequences and the chamber was dark. Responses on the incorrect lever had no programmed consequences other than to reset the FR requirement on the correct lever. After each time out, the white house light was again turned on and the next trial began. Each session ended after completion of $20 \mathrm{FR}$ trials or after $30 \mathrm{~min}$, whichever occurred first. Discrimination-training sessions were conducted 5 days per week under a double alternation schedule (ie, NNSSNNSS, etc., $\mathrm{N}=$ nicotine; $\mathrm{S}=$ saline). Training continued until there were eight consecutive sessions during which rats completed at least $90 \%$ of their responses during the session on the appropriate lever and no more than four responses occurred on the inappropriate lever during the first trial.

Effects of L-745,870 on nicotine discrimination. After acquisition of nicotine discrimination, test sessions with other doses of nicotine and with the DRD4 antagonist L-745,870 were initiated. Once again, a within-subjects Latin square design was used (ie, the same rats received the various treatments regimen during various test sessions). All doses of L-745,870 (0.1-3.0 mg/kg, i.p., $30 \mathrm{~min}$ before the start of the session) were administered alone to examine its ability to produce responding on the nicotine-associated lever (ie, to produce a 'nicotine-like' effect). The highest three doses of L-745,870 were administered with various doses of nicotine $(0.01,0.03,0.1,0.3,0.4 \mathrm{mg} / \mathrm{kg})$ and effects on the dose-effect curve for nicotine discrimination were examined. The percentage of nicotine-associated lever responses and the response rate were recorded. Test sessions were identical to training sessions, with the exception of both levers being active and 10 consecutive responses on either 1 of the 2 levers resulting in the delivery of a food pellet. Switching responding from one lever to the other lever reset the ratio requirement. In a test phase, a single alternation schedule was introduced and test sessions were usually conducted on Tuesdays and Fridays. Thus, a 2-week sequence starting on Monday was NTSNTSTNST $(T=$ test). In this manner, test sessions occurred with equal probability after saline and nicotine sessions. Test sessions were conducted only if the criterion of $90 \%$ accuracy and not more than four incorrect responses during the first trial was maintained in the two most recent training sessions.

\section{Data Analysis}

A two-way repeated-measures analysis of variance (ANOVA), followed by post hoc Bonferroni's test was performed for the difference in the number of active $v s$ inactive lever presses during acquisition of nicotine self-administration, nicotine extinction training, acquisition of food selfadministration, food extinction training, and acquisition of nicotine discrimination. Paired Student's $t$-tests were conducted between baseline and vehicle responding during testing for nicotine-taking, nicotine- and food-seeking behaviors. Subsequently, a one-way repeated-measures ANOVA, followed by post hoc Newman-Keuls multiple comparisons were used to examine the effects of the different doses of L-745,870 on nicotine-taking, cue-induced, or nicotine-primed reinstatement of nicotine-seeking behavior, cue-induced, or food-primed reinstatement of food-seeking behavior and nicotine discrimination.

\section{RESULTS}

\section{No Effect of the Selective DRD4 Antagonist L-745,870 on Nicotine Self-Administration}

After animals had acquired stable self-administration, pretreatment with L-745,870 doses ranging from 0.1 to $3.0 \mathrm{mg} / \mathrm{kg}$ (i.p.) did not affect the number of nicotine infusions self-administered, compared with vehicle treatment (Figure 1a, ANOVA, $p>0.05$ ). L-745,870 pretreatment at the doses tested also did not alter either active lever presses or inactive lever presses (Figure 1b, ANOVA, $p>0.05$ ). These results suggest that the role of $\mathrm{D} 4$ receptors in modulating the reinforcing effects of nicotine is minimal at best.

\section{Attenuation of Cue-Induced Reinstatement of Nicotine-Seeking Behavior by L-745,870}

After extinction of their nicotine-seeking behavior, animals showed clear cue-induced reinstatement of nicotine-seeking behavior after vehicle pretreatment compared with baseline extinction (paired Student's $t$-test of baseline $v s$ vehicle, $p<0.001$ ). In contrast, L-745,870 pretreatment, at doses ranging from 0.1 to $3.0 \mathrm{mg} / \mathrm{kg}$, significantly decreased the number of active lever presses induced by nicotineassociated cues (Figure 2a, upper panel, ANOVA with post hoc Newman-Keuls comparison, $p<0.01,0.05,0.05,0.01$, respectively), although there was no difference in the number of inactive lever presses during these tests (Figure 2a, lower panel, ANOVA, $p>0.05$ ). These findings suggest that D4 receptors are important for cue-induced relapse to nicotine-seeking behavior.

\section{Attenuation of Nicotine-Primed Reinstatement of Nicotine-Seeking Behavior by L-745,870}

In the group of rats trained to self-administer nicotine, which subsequently underwent extinction of their nicotineseeking behavior, a priming injection of nicotine $(0.15 \mathrm{mg} / \mathrm{kg}$, s.c.) reliably induced reinstatement of nicotine-seeking behavior (paired Student's $t$-test of baseline $v s$ vehicle, $p<0.001)$. Pretreatment with L-745,870 over the dose range 

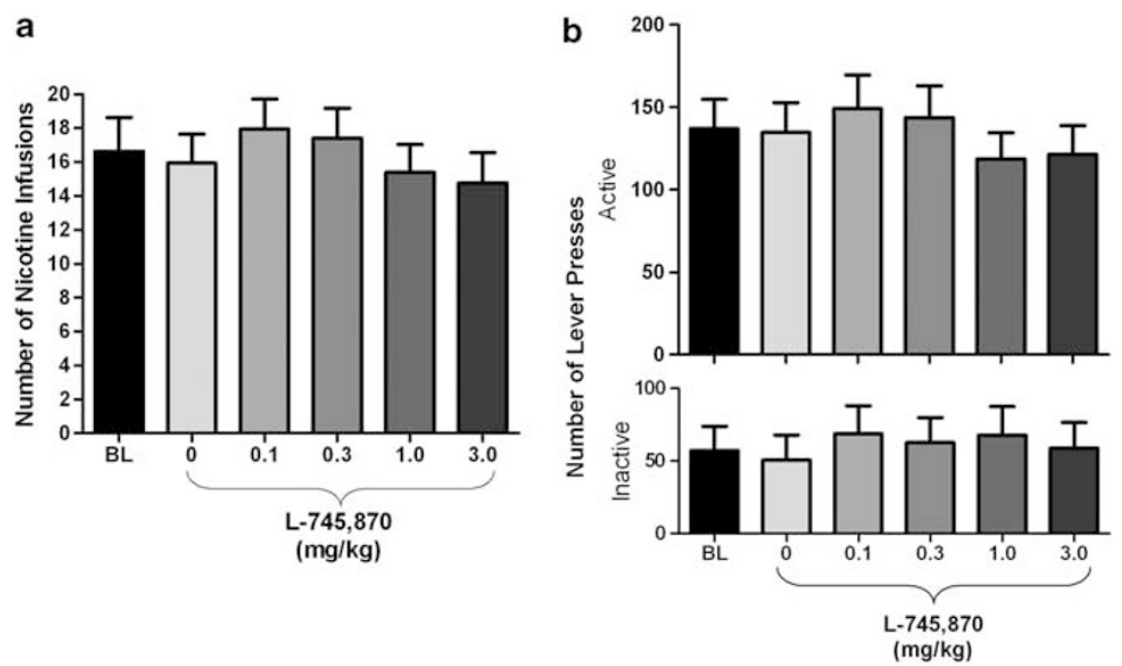

Figure I Effect of DRD4 antagonist L-745,870 on nicotine self-administration behavior under a fixed ratio (FR5) schedule in rats. (a) No effect of $L-745,870$ at the dose range of $0.1-3.0 \mathrm{mg} / \mathrm{kg}$ on the number of nicotine infusions. (b) No effect of $L-745,870$ at the dose range of $0.1-3.0 \mathrm{mg} / \mathrm{kg}$ on the number of active and inactive lever presses. $N=13$. Data are expressed as means ( \pm SEM) of the number of injections per session during baseline conditions (baseline) and during sessions with vehicle $(0 \mathrm{mg} / \mathrm{kg})$ or $\mathrm{L}-745,870$ pretreatment. The antagonist did not alter nicotine-taking behavior.

a

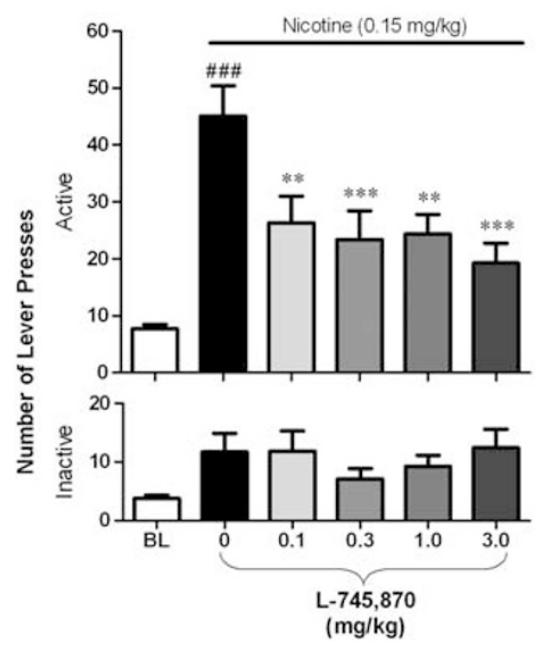

b

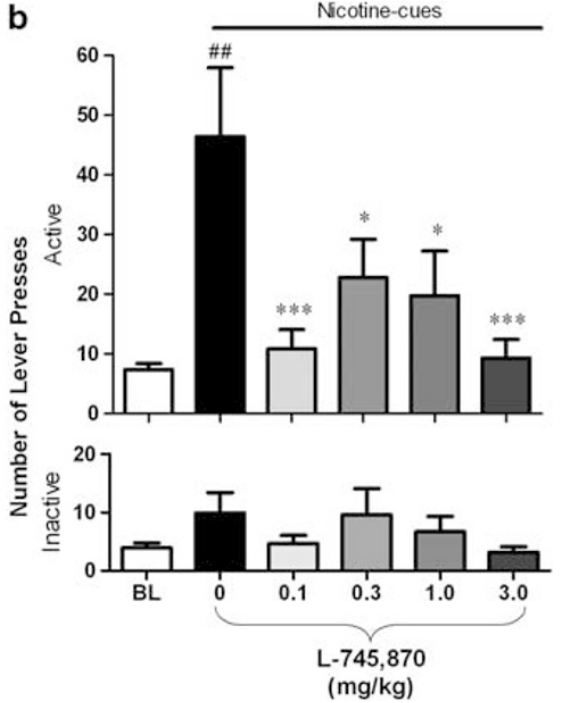

Figure 2 Effect of DRD4 antagonist L-745,870 on the reinstatement of nicotine-seeking behavior in rats. (a) Pretreatment of L-745,870 significantly reduced the number of active (upper) but not inactive (lower) lever presses triggered by nicotine-associated cues. $N=13$. (b) Pretreatment of $L-745,870$ significantly attenuated the number of active (upper) but not inactive (lower) lever presses induced by priming injection of nicotine $(0.15 \mathrm{mg} / \mathrm{kg}, \mathrm{s.c}$.). $\mathrm{N}=23$. $* p<0.05$, *** $p<0.0$ I, **** $p<0.00$ I vs the baseline (without nicotine-associated cues); Student's paired $t$-test. \#\# $p<0.0$ I, \#\#\# $p<0.00$ I vs the vehicle pretreatment; Newman-Keuls multiple comparison test after significant ANOVA for repeated measures. Data are expressed as means ( \pm SEM) of the number of lever presses during extinction training, during baseline conditions (baseline), and during sessions with vehicle $(0 \mathrm{mg} / \mathrm{kg})$ or $\mathrm{L}-745,870$ pretreatment.

of $0.1-3.0 \mathrm{mg} / \mathrm{kg}$ (i.p.) significantly reduced the number of active lever presses induced by a priming injection of nicotine (Figure $2 \mathrm{~b}$, upper panel, ANOVA with post hoc Newman-Keuls comparison, $p<0.01,0.01,0.01,0.001$, respectively), whereas there was no change in the number of inactive lever presses during these tests (Figure $2 b$, lower panel, ANOVA, $p>0.05$ ) across different doses of L-745,870. These observations indicate that $\mathrm{D} 4$ receptors have an important role in nicotine-primed reinstatement of nicotine-seeking behavior and in cue-induced reinstatement of nicotine-seeking behavior.

\section{No Effect of L-745,870 on Reinstatement of Food-Seeking Behavior Induced by either Food Priming or Food-Associated Cues}

In the group of rats trained to self-administer food, which subsequently underwent extinction of their food-seeking behavior, priming with food pellets reliably induced reinstatement of food-seeking behavior (paired Student's $t$-test of baseline $v s$ vehicle, $p<0.001$ ). However, L-745,870 doses ranging from 0.1 to $3.0 \mathrm{mg} / \mathrm{kg}$ (i.p.) did not affect reinstatement of food-seeking behavior (Figure 3a, upper 

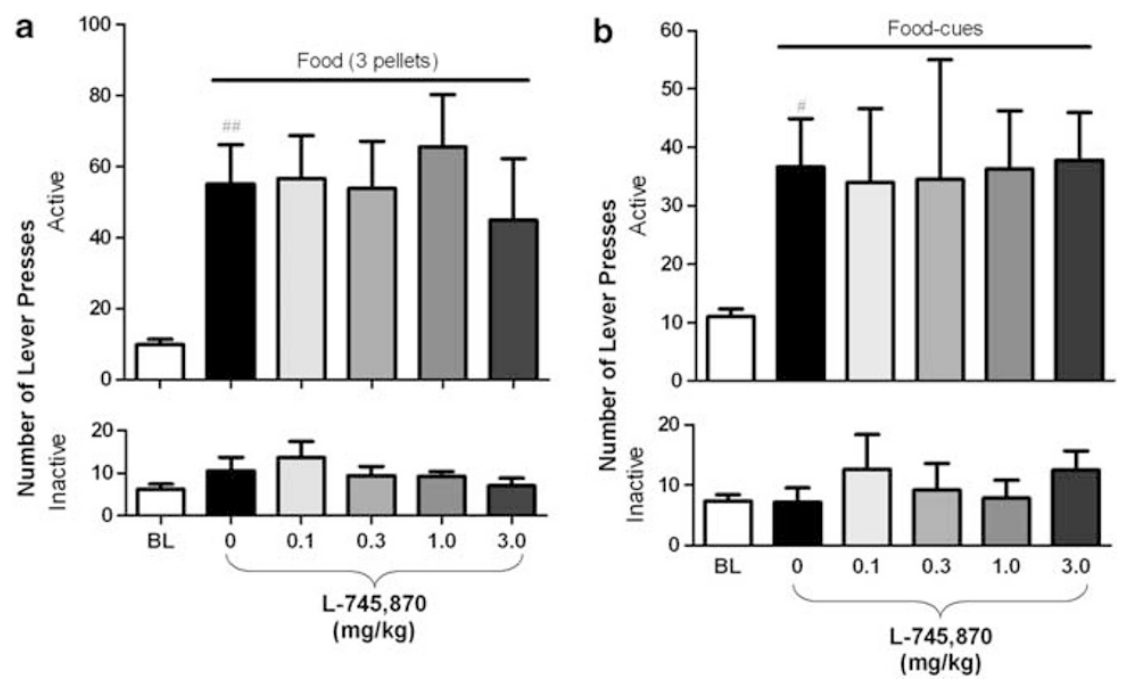

Figure 3 Effect of DRD4 antagonist L-745,870 on reinstatement of food-seeking behavior induced by either food-priming or food-associated cues in rats. (a) Pretreatment of $L-745,870$ did not affect food-primed reinstatement of food-seeking behavior. ${ }^{\# \# ~} p<0.0$ I vs the baseline; Student's paired $t$-test. (b) Pretreatment of L-745,870 did not influence food cue-induced reinstatement of food-seeking behavior. ${ }^{\#} p<0.05$ vs the baseline; Student's paired $t$-test. $N=6-10$. Data are expressed as means $( \pm S E M)$ of the number of active lever presses during baseline conditions (baseline) and during sessions with vehicle $(0 \mathrm{mg} / \mathrm{kg})$ or L-745,870 pretreatment.

panel, ANOVA, $p>0.05)$. Similarly, food-associated cues also reliably induced reinstatement of food-seeking behavior (paired Student's $t$-test of baseline $v s$ vehicle, $p<0.01$ ) and L-745,870, at all doses tested, failed to alter cue-induced reinstatement of food-seeking behavior (Figure 3b, upper panel, ANOVA, $p>0.05$ ).

\section{No Effect of the Selective DRD4 Agonist PD 168,077 on Nicotine- or Food-Seeking Behavior during Extinction}

In the group of rats trained to self-administer nicotine, which subsequently underwent extinction of their nicotineseeking behavior, PD 168,077 (dose range $0.3-3.0 \mathrm{mg} / \mathrm{kg}$; i.p.), did not affect active lever responding during nicotine extinction sessions (ANOVA, $p>0.05$ ).

Another group of naive rats was first trained to selfadminister food pellets and then subjected to extinction training as described above. Once criteria for extinction were met, tests for effects of PD 168,077 on food-seeking behavior began. PD 168,077 (dose range $0.3-3.0 \mathrm{mg} / \mathrm{kg}$; i.p.) did not affect active lever responding during food extinction sessions (ANOVA, $p>0.05$ ).

\section{No Effect of the Selective DRD4 Antagonist L-745,870 on Nicotine Discrimination}

A two-way ANOVA on the percentage of nicotine-associated lever responses for the dose-response curve for nicotine discrimination $(0.01-0.4 \mathrm{mg} / \mathrm{kg})$, with or without L-745,870 pretreatment $(0.3-3 \mathrm{mg} / \mathrm{kg})$, indicated a significant nicotine effect $\left(\mathrm{F}_{(5,241)}=323, p<0.0001\right)$, and post hoc analysis showed a dose-dependent increase in nicotine-lever selection with maximal nicotine-lever selection at the $0.4 \mathrm{mg} / \mathrm{kg}$ training dose of nicotine (Figure 4a). L-745,870 did not significantly affect the percentage of nicotine-associated lever responses for any dose of nicotine (Figure 4a, ANOVA,
L-745,870 effect: $\left.\mathrm{F}_{(3,241)}=1.225, p>0.05\right)$, indicating that DRD4 blockade did not alter the discriminative effects of nicotine in rats. A second ANOVA was performed on the rate of lever responding, which indicated a significant effect of both nicotine $\left(\mathrm{F}_{(5,241)}=2.86, p<0.05\right)$ and $\mathrm{L}-745,870$ $\left(\mathrm{F}_{(3,241)}=2.88, p<0.05\right)$, but no significant interaction (Figure $\left.4 \mathrm{~b}, \mathrm{~F}_{(15,241)}=0.46, p>0.05\right)$. However, post hoc analysis revealed that only the $3.0 \mathrm{mg} / \mathrm{kg}$ dose of L-745,870 significantly decreased the rate of lever responding when compared with vehicle, but only at the $0.3 \mathrm{mg} / \mathrm{kg}$ dose of nicotine $(p<0.05)$. Finally, L-745,870 did not produce any nicotine-like discriminative effects $(<5 \%$ of responses emitted on nicotine-associated lever) at any of the three doses examined (Figure 4c, ANOVA, L-745,870 effect: $\left.\mathrm{F}_{(3,79)}=0.675, \quad p>0.05\right)$, nor did it produce any effects on rate of lever-press responding (Figure $4 \mathrm{~d}$ ANOVA, L-745,870 effect: $\left.\mathrm{F}_{(3,79)}=0.63, p>0.05\right)$.

\section{DISCUSSION}

In this study, we demonstrated that the selective DRD4 antagonist, L-745,870, significantly attenuates both nicotine- and cue-induced reinstatement of nicotine-seeking behavior in rats, but does not alter the ability of rats to discriminate nicotine from saline. Yet, over the same dose range, L-745,870 has no effect on ongoing nicotine selfadministration behavior and does not alter food- or cueinduced reinstatement of food-seeking behavior. In clinical studies, polymorphisms of the DRD4 gene have been linked to chronic alcoholism, tobacco smoking, opioid dependence, impulsivity, and novelty-seeking behavior, which are considered potential predictors of vulnerability to drugs of abuse (Chien et al, 2010; Ebstein et al, 1996; George et al, 1993; Ho et al, 2008; Kotler et al, 1997; Li et al, 2000; Luciano et al, 2004). Previously, polymorphisms of DRD4 were reported to modulate DRD4 expression, decrease 

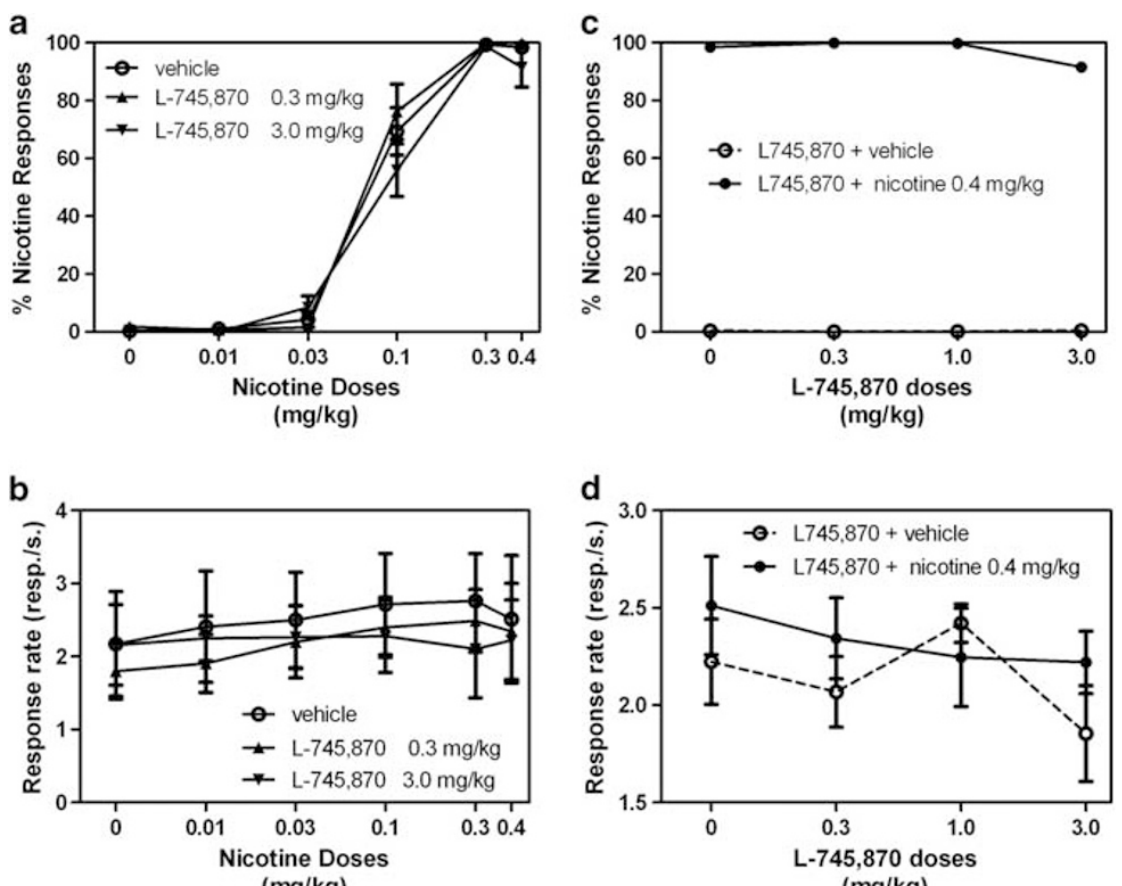

$(\mathrm{mg} / \mathrm{kg})$

$(\mathrm{mg} / \mathrm{kg})$

Figure 4 (a) Dose-effect functions for the discriminative-stimulus effects of nicotine in rats trained to discriminate $0.4 \mathrm{mg} / \mathrm{kg}$ nicotine from saline. The percentage of responses on the lever associated with nicotine administration is shown as a function of dose $(\mathrm{mg} / \mathrm{kg})$ during tests with various doses of nicotine. The DRD4 antagonist L-745,870, administered acutely 30 min before the sessions, did not modify discriminative-stimulus effects of nicotine (no curve shift). (b) L-745,870 also did not significantly affect rates of lever-press responding when administered together with different doses of nicotine or with vehicle. (c) Effects of different doses of L-745,870 on discriminative-stimulus effects of the training dose of nicotine when L-745,870 was administered with vehicle. (d) Effects of different doses of L-745,870 on rates of lever-press responding when administered together with the training dose of nicotine or with vehicle. $N=9-12$. Data are expressed as means ( \pm SEM) of the percentage of responses on the nicotine lever.

ligand binding to DRD4, and attenuate the resulting cAMP formation (Asghari et al, 1994, 1995; Cohen et al, 1992; Le Foll et al, 2009 for review). More recently, the VNTR polymorphism of the DRD4 gene has been correlated with smoking cue reactivity, cocaine cue reactivity, and alcoholand heroin-craving behavior (Hutchison et al, 2002a, b, 2003, 2006; McClernon et al, 2007; Munafo and Johnstone, 2008; Shao et al, 2006). In addition, previous animal studies have demonstrated that DRD4 blockade with L-745,870 blocks the discriminative-stimulus effects of methamphetamine in rats (Yan et al, 2004, 2006) and attenuates the morphine-induced withdrawal syndrome precipitated by naloxone (Mamiya et al, 2004). The data presented here suggest that DRD4 is very likely involved in relapse to tobacco smoking behavior. Along with the above-mentioned evidence, our data also suggest DRD4 as a potential target for development of therapeutic agents against certain aspects of addictive behavior, particularly tobacco smoking relapse.

It has been reported that, in the nicotine self-administration paradigm, nicotine itself has two actions: a primary reinforcing effect and a non-associative enhancement of responding for weakly reinforcing visual stimuli, or 'reinforcement-enhancing' effect (Chaudhri et al, 2006a, b; Palmatier et al, 2006, 2007a,b). In this study, we observed that blockade of DRD4 with L-745,870 failed to affect nicotine self-administration. It is difficult to determine whether this failure resulted from an inability of DRD4 blockade to alter the primary reinforcing effect of nicotine or the reinforcement-enhancing effect of nicotine; however, future study should further explore this aspect.

It has been previously reported that blockade of DRD4 with L-745,870 (dose range $0.1-10.0 \mathrm{mg} / \mathrm{kg}$ ) does not affect cocaine self-administration in rats (Caine et al, 2002). Moreover, deletion of the $D R D 4$ gene in mice does not affect food or cocaine self-administration behavior (Thanos et al, 2010). These findings are in agreement with our observation in this study that L-745,870 $(0.1-3.0 \mathrm{mg} / \mathrm{kg})$ did not alter nicotine self-administration behavior. It seems unlikely that this lack of effect of L-745,870 is due to insufficient dosage, as estimates of D4 receptor occupancy in vivo suggest that $1.0 \mathrm{mg} / \mathrm{kg}$ of L-745,870 occupies up to $90 \%$ of D4 receptors in the mouse brain (Patel et al, 1997). In addition, it is interesting to note that the blockade of another member of the D2-like receptor family, DRD3, also fails to affect nicotine-taking behavior, yet attenuates the reinstatement of nicotine-seeking behavior (Khaled et al, 2010; Andreoli et al, 2003). As L-745,870 had no effect on nicotine discrimination, it is unlikely that its effect on nicotineseeking behavior was due to a reduced ability of rats to discriminate the effects of nicotine. Moreover, it is unlikely that the dissociable effects of L-745,870 on nicotine-taking behavior vs nicotine relapse resulted from food training before nicotine self-administration, as there was no effect of L-745,870 on food-seeking behavior induced by presentation of food pellets or food-associated cues. In contrast, the fact that blockade of DRD4 with L-745,870 did not affect nicotine-taking behavior, but disrupted reinstatement 
of nicotine-seeking behavior, may be due to scarce distribution of D4 receptors in reinforcement-related brain subregions.

The expression of DRD4 is most abundant in the retina, followed by the prefrontal cortex, hippocampus, amygdala, and hypothalamus, but the level of DRD4 is sparse in the basal ganglia, including the nucleus accumbens (Cohen et al, 1992; Khan et al, 1998; Oak et al, 2000). The relatively low level of DRD4 expression that does exist in the shell of nucleus accumbens appears to be mainly localized on presynaptic structures (Svingos et al, 2000). The DRD4 is also found on both pyramidal and non-pyramidal neurons of the cerebral cortex, particularly layer $\mathrm{V}$, and in the hippocampus, where they are known to regulate both GABAergic signaling and NMDA receptor surface expression (Mrzljak et al, 1996; Wang et al, 2002, 2003). Overall, the expression pattern of DRD4 in the brain suggests that DRD4 activity participates only marginally in the reinforcing effects of abused drugs such as nicotine and cocaine. The lack of effect of intra-accumbal administration of L-750,667, another selective DRD4 antagonist, on cocaineseeking behavior (Anderson et al, 2006) supports the view that expression of DRD4 is too low in the nucleus accumbens (Khan et al, 1998; Oak et al, 2000) to modulate the reinforcing effects of abused drugs. In contrast, brain areas such as the insular cortex or the frontal cortex, which more abundantly express DRD4 are more likely to mediate the inhibitory effects of L-745,870 on nicotine-seeking behavior induced either by a nicotine prime or by nicotine-associated cues (Forget et al, 2010; Hai-Bin et al, 2005). This hypothesis seems to be in agreement with recent clinical and preclinical animal studies showing that the insular cortex is critical for tobacco smoking behavior (Forget et al, 2010; Janes et al, 2010; McClernon et al, 2007; Naqvi et al, 2007).

In this study, the DRD4 antagonist L-745,870 at all doses tested, significantly attenuated reinstatement of nicotineseeking behavior induced either by nicotine-associated cues or by a priming injection of nicotine. Interestingly, across the doses studied $(0.1-3.0 \mathrm{mg} / \mathrm{kg}$, i.p.), L-745,870 did not show a typical pharmacological dose-effect function for blockade of reinstatement of nicotine-seeking behavior. In the paradigm of methamphetamine discrimination, it was also found that L-745,870, at all doses tested (0.025-0.5 mg/kg, i.p.), significantly attenuated the discriminative-stimulus effects of methamphetamine in rats, yet it also did not show a typical pharmacological dose-effect function (Yan et al, 2006). A previous in vivo study confirmed that a dose of $0.035 \mathrm{mg} / \mathrm{kg}$ of $\mathrm{L}-745,870$ is sufficient to occupy 50\% DRD4 in the mouse brain (Patel et al, 1997), whereas, in our current study, the lowest dose of $0.1 \mathrm{mg} / \mathrm{kg}$ is about three times greater. One parsimonious explanation is that occupancy of DRD4 by L-745,870, at all of doses tested in this study, was sufficient to fully block the bioactivity of DRD4 in the rat brain. With regard to the inability of L-745,870 to affect nicotine discrimination, one possible explanation is that the DRD4 is specifically involved in relapse to nicotine-seeking behavior, but not in the discriminative-stimulus effects of nicotine in rats. However, it is noteworthy that different rat strains have been used in this study for nicotine discrimination and nicotine self-administration, and that differences in rat strains can be an important factor in the development of drug dependence and relapse (Hamilton et al, 2010; Kacew and Festing, 1996).

In this study, the DRD4 agonist PD 168,077, at all doses tested, failed to reinstate nicotine-seeking behavior in rats, although the selective DRD4 antagonist L-745,870 significantly reduced reinstatement of nicotine-seeking behavior. It seems unlikely that the failure of PD 168,077 to induce nicotine-seeking behavior resulted from a low selectivity for DRD4, because the agonist has been demonstrated to be highly selective for DRD4, showing low binding affinities for other dopaminergic, adrenergic, or serotoninergic receptors (eg, with >100-fold selectivity over DRD1, >400-fold selectivity over DRD2, and >300-fold selectivity vs DRD3) (Glase et al, 1997). It also seems unlikely that the failure of PD 168,077 to induce nicotine-seeking behavior resulted from an insufficient dosage as a similar range of doses has been used to elucidate the specific function of DRD4 in in vivo studies (Bernaerts and Tirelli, 2003; Gago et al, 2007; Nayak and Cassaday, 2003). Previously, it was reported that the role of both DRD1 antagonists and agonists in the reinstatement of cocaine-seeking behavior is dissociable in rats: a selective DRD1 antagonist, $\mathrm{SCH} 23390$, attenuates, whereas a selective DRD1 agonist has no affect on, the reinstatement of cocaine-seeking behavior in rats (Self, 2004). In addition, it was also reported that co-activation of DRD1 and DRD2 is required for long-term synaptic depression in the striatum (Calabresi et al, 1992) and that long-term synaptic depression in the basal ganglia is critical for drug-seeking behavior (Kasanetz et al, 2010; Thomas et al, 2008). These findings suggest that co-activation of dopamine D1-like and D2-like receptors is essential for the reinstatement of drug-seeking behavior (Ikemoto et al, 1997; Schmidt and Pierce, 2006). The hypothesis of coactivation of D1-and D2-like receptors may lay a framework for the dissociable role of both dopamine receptor antagonists and agonists in the reinstatement of drugseeking behavior. Accordingly, it seems reasonable to postulate that DRD4 is a key component in the reinstatement of nicotine-seeking behavior, but its activation alone is insufficient for inducing reinstatement of nicotine-taking behavior. In addition, using the drug-conditioned placepreference paradigm, it was also reported that another selective DRD4 agonist (A-412997) does not produce conditioned place preference, a measure of reward in rats (Woolley et al, 2008), although there no information is available for the effect of DRD4 antagonists on rewardrelated behavior with the place-preference paradigm. Future studies should examine the potential interaction between DRD4 and DRD1-like or other DRD2-like subtypes during reinstatement of nicotine-seeking behavior.

Previously, it was reported that DRD4 knockout mice are supersensitive to the psychomotor stimulant effects of ethanol, cocaine, methamphetamine, and amphetamine (Katz et al, 2003; Kruzich et al, 2004; Rubinstein et al, 1997). Cocaine has also been reported to be more potent in stimulating locomotor activity and in producing discriminative-stimulus effects in DRD4 knockout mice compared with wild-type littermates (Katz et al, 2003). These findings suggest that DRD4 functions as an inhibitory modulator of locomotor stimulation induced by abused drugs. On the basis of these findings, it would be expected that 
pharmacological blockade of DRD4 should produce changes in the behavioral effects of abused drugs similar to those observed in DRD4 knockout mice. More recently, it has been reported that DRD4 knockouts do not show any difference from wild-type mice in food-reinforced operant behavior or in cocaine self-administration behavior (Thanos et al, 2010). These findings seem to be in discrepancy with our results in this report. One possible explanation for contrasting observations is that differences between the effects of DRD4 gene deletion and pharmacological blockade of DRD4 on the behavioral effects of abused drugs results from compensatory adjustments to DRD4 gene deletion during development. For example, expression of DRD1 and glutamate NMDA receptors is enhanced in the forebrain of DRD4 knockout mice (Gan et al, 2004), and DRD4 knockout mice exhibit neurochemical changes consistent with decreased dopamine release (Thomas et al, 2007).

In conclusion, our new results suggest that DRD4 is critical for nicotine relapse behavior, but are not involved in nicotine-taking behavior, natural reward-seeking behavior, or in the discriminative-stimulus effects of nicotine. Recently, there has been a marked interest in DRD4 involvement in psychiatric diseases (Hoenicka et al, 2007), and these findings suggest that the DRD4 is critically involved in the pressing problem of tobacco dependence. High relapse rates after smoking cessation constitute, perhaps, the major impediment to successful treatment of tobacco dependence (Hughes et al, 2004), and our findings may point to pharmacological blockade of DRD4 as a novel and potentially effective treatment against relapse to tobacco smoking in clinical situations. Future identification of the precise subregion(s) and molecular mechanism(s) underlying the pharmacological effects of the selective DRD4 antagonist L-745,870 on relapse to nicotine-seeking behavior that we observed in the present experiments would help to elucidate the in vivo role of this receptor subtype in nicotine abuse and tobacco dependence.

\section{ACKNOWLEDGEMENTS}

We thank Drs John Roder and Benoit Forget for their comments on our experimental data. This study was supported partly by the Canadian Tobacco Control Research Initiate (CTCRI) Student Research Grant (no. 20040), by the Canadian Institute of Health Research (CIHR) postdoctoral fellowship (Code No. 200810MFE193820-172560), by the CIHR Strategic Training Program in Tobacco Use in Special Populations (TUSP) postdoctoral fellowship and in part by the Intramural Research Program of the National Institute on Drug Abuse.

\section{DISCLOSURE}

The authors declare no conflict of interest.

\section{REFERENCES}

Anderson SM, Schmidt HD, Pierce RC (2006). Administration of the D2 dopamine receptor antagonist sulpiride into the shell, but not the core, of the nucleus accumbens attenuates cocaine priming-induced reinstatement of drug seeking. Neuropsychopharmacology 31: 1452-1461.

Andreoli M, Tessari M, Pilla M, Valerio E, Hagan JJ, Heidbreder CA (2003). Selective antagonism at dopamine D3 receptors prevents nicotine-triggered relapse to nicotine-seeking behavior. Neuropsychopharmacology 28: 1272-1280.

Asghari V, Sanyal S, Buchwaldt S, Paterson A, Jovanovic V, Van Tol HH (1995). Modulation of intracellular cyclic AMP levels by different human dopamine D4 receptor variants. J Neurochem 65: 1157-1165.

Asghari V, Schoots O, Van Kats S, Ohara K, Jovanovic V, Guan H$C$ et al (1994). Dopamine $\mathrm{D}_{4}$ receptor repeat: analysis of different native and mutant forms of the human and rat genes. Mol Pharmacol 46: 364-373.

Bernaerts P, Tirelli E (2003). Facilitatory effect of the dopamine D4 receptor agonist PD168,077 on memory consolidation of an inhibitory avoidance learned response in C57BL/6J mice. Behav Brain Res 142: 41-52.

Brady KT, Sinha R (2005). Co-occurring mental and substance use disorders: the neurobiological effects of chronic stress. Am J Psychiatry 162: 1483-1493.

Caine SB, Negus SS, Mello NK, Patel S, Bristow L, Kulagowski J et al (2002). Role of dopamine D2-like receptors in cocaine selfadministration: studies with D2 receptor mutant mice and novel D2 receptor antagonists. J Neurosci 22: 2977-2988.

Calabresi P, Maj R, Pisani A, Mercuri NB, Bernardi G (1992). Longterm synaptic depression in the striatum: physiological and pharmacological characterization. J Neurosci 12: 4224-4233.

Chaudhri N, Caggiula AR, Donny EC, Booth S, Gharib M, Craven L et al (2006a). Operant responding for conditioned and unconditioned reinforcers in rats is differentially enhanced by the primary reinforcing and reinforcement-enhancing effects of nicotine. Psychopharmacology (Berl) 189: 27-36.

Chaudhri N, Caggiula AR, Donny EC, Palmatier MI, Liu X, Sved AF (2006b). Complex interactions between nicotine and nonpharmacological stimuli reveal multiple roles for nicotine in reinforcement. Psychopharmacology (Berl) 184: 353-366.

Chien CC, Lin CH, Chang YY, Lung FW (2010). Association of VNTR polymorphisms in the MAOA promoter and DRD4 exon 3 with heroin dependence in male Chinese addicts. World J Biol Psychiatry 11(2 Pt 2): 409-416.

Cohen AI, Todd RD, Harmon S, O’ Malley KL (1992). Photoreceptors of mouse retinas possess $\mathrm{D}_{4}$ receptors coupled to adenylate cyclase. Proc Natl Acad Sci USA 89: 12093-12097.

Corrigall WA (1999). Nicotine self-administration in animals as a dependence model. Nicotine Tobacco Res 1: 11-20.

Corrigall WA, Coen KM (1989). Nicotine maintains robust selfadministration in rats on a limited-access schedule. Psychopharmacology (Berlin) 99: 473-478.

Corrigall WA, Coen KM (1991). Selective dopamine antagonists reduce nicotine self-administration. Psychopharmacology (Berl) 104: 171-176.

Corrigall WA, Franklin KB, Coen KM, Clarke PB (1992). The mesolimbic dopaminergic system is implicated in the reinforcing effects of nicotine. Psychopharmacology (Berl) 107: 285-289.

Dalack GW, Healy DJ, Meador-Woodruff JH (1998). Nicotine dependence in schizophrenia: clinical phenomena and laboratory findings. Am J Psychiatry 155: 1490-1501.

Di Chiara G (2000). Role of dopamine in the behavioural actions of nicotine related to addiction. Eur J Pharmacol 393: 295-314.

DiFranza J, Ursprung WW (2010). A systematic review of the International Classification of Diseases criteria for the diagnosis of tobacco dependence. Addict Behav 35: 805-810.

Donny EC, Caggiula AR, Knopf S, Brown C (1995). Nicotine self-administration in rats. Psychopharmacology (Berlin) 122: 390-394.

Ebstein RP, Novick O, Umansky R, Priel B, Osher Y, Blaine D et al (1996). Dopamine D4 receptor (D4DR) exon III polymorphism 
associated with the human personality trait of Novelty Seeking. Nat Genet 12: 78-80.

Forget B, Pushparaj A, Le Foll B (2010). Granular insular cortex inactivation as a novel therapeutic strategy for nicotine addiction. Biol Psychiatry 68: 265-271.

Gago B, Fuxe K, Agnati L, Penafiel A, De La Calle A, Rivera A (2007). Dopamine $D(4)$ receptor activation decreases the expression of mu-opioid receptors in the rat striatum. J Comp Neurol 502: 358-366.

Gan L, Falzone TL, Zhang K, Rubinstein M, Baldessarini RJ, Tarazi FI (2004). Enhanced expression of dopamine $\mathrm{D}(1)$ and glutamate NMDA receptors in dopamine $\mathrm{D}(4)$ receptor knockout mice. J Mol Neurosci 22: 167-178.

Gelernter J, Liu X, Hesselbrock V, Page GP, Goddard A, Zhang H (2004). Results of a genome-wide linkage scan: support for chromosomes 9 and 11 loci increasing risk for cigarette smoking. Am J Med Genet B Neuropsychiatr Genet 128B: 94-101.

George SR, Cheng R, Nguyen T, Israel Y, O’Dowd BF (1993). Polymorphisms of the D4 dopamine receptor alleles in chronic alcoholism. Biochem Biophys Res Commun 196: 107-114.

Glase SA, Akunne HC, Georgic LM, Heffner TG, MacKenzie RG, Manley PJ et al (1997). Substituted [(4-phenylpiperazinyl)methyl]benzamides: selective dopamine D4 agonists. J Med Chem 40: 1771-1772.

Goldberg SR, Spealman RD, Goldberg DM (1981). Persistent behavior at high rates maintained by intravenous self-administration of nicotine. Science 214: 573-575.

Hai-Bin T, Duan-Zhi Y, Lan Z, Li-Hua W, Chun-Fu Z, Ming-Wei W et al (2005). Dopamine $\mathrm{D}(4)$ receptor antagonist 3- $(4-[(18) \mathrm{F}]$ fluorobenzyl)-8-methoxy-1,2,3,4-tetrahydrochromeno[3,4-c]pyrid in-5-one([(18)F]FMTP): radiosynthesis and in vivo characterization in rats. Appl Radiat Isot 63: 333-342.

Haile CN, Kosten TA (2001). Differential effects of D1- and D2-like compounds on cocaine self-administration in Lewis and Fischer 344 inbred rats. J Pharmacol Exp Ther 299: 509-518.

Hamilton KR, Perry ME, Berger SS, Grunberg NE (2010). Behavioral effects of nicotine withdrawal differ by genetic strain in male and female adolescent rats. Nicotine Tob Res 12: $1236-1245$.

Hitsman B, Moss TG, Montoya ID, George TP (2009). Treatment of tobacco dependence in mental health and addictive disorders. Can J Psychiatry 54: 368-378.

Ho AM, Tang NL, Cheung BK, Stadlin A (2008). Dopamine receptor D4 gene $-521 \mathrm{C} / \mathrm{T}$ polymorphism is associated with opioid dependence through cold-pain responses. Ann NY Acad Sci 1139: 20-26.

Hoenicka J, Aragues M, Ponce G, Rodriguez-Jimenez R, JimenezArriero MA, Palomo T (2007). From dopaminergic genes to psychiatric disorders. Neurotox Res 11: 61-72.

Hughes JR, Keely J, Naud S (2004). Shape of the relapse curve and long-term abstinence among untreated smokers. Addiction 99: 29-38.

Hutchison KE, LaChance H, Niaura R, Bryan A, Smolen A (2002a). The DRD4 VNTR polymorphism influences reactivity to smoking cues. J Abnorm Psychol 111: 134-143.

Hutchison KE, McGeary J, Smolen A, Bryan A, Swift RM (2002b). The DRD4 VNTR polymorphism moderates craving after alcohol consumption. Health Psychol 21: 139-146.

Hutchison KE, Ray L, Sandman E, Rutter MC, Peters A, Davidson $\mathrm{D}$ et al (2006). The effect of olanzapine on craving and alcohol consumption. Neuropsychopharmacology 31: 1310-1317.

Hutchison KE, Wooden A, Swift RM, Smolen A, McGeary J, Adler L et al (2003). Olanzapine reduces craving for alcohol: a DRD4 VNTR polymorphism by pharmacotherapy interaction. Neuropsychopharmacology 28: 1882-1888.

Ikemoto S, Glazier BS, Murphy JM, McBride WJ (1997). Role of dopamine D1 and D2 receptors in the nucleus accumbens in mediating reward. J Neurosci 17: 8580-8587.
Janes AC, Pizzagalli DA, Richardt S, de BFB, Chuzi S, Pachas G et al (2010). Brain reactivity to smoking cues prior to smoking cessation predicts ability to maintain tobacco abstinence. Biol Psychiatry 67: 722-729.

Kacew S, Festing MF (1996). Role of rat strain in the differential sensitivity to pharmaceutical agents and naturally occurring substances. J Toxicol Environ Health 47: 1-30.

Kasanetz F, Deroche-Gamonet V, Berson N, Balado E, Lafourcade $\mathrm{M}$, Manzoni $\mathrm{O}$ et al (2010). Transition to addiction is associated with a persistent impairment in synaptic plasticity. Science 328: 1709-1712.

Katz JL, Chausmer AL, Elmer GI, Rubinstein M, Low MJ, Grandy DK (2003). Cocaine-induced locomotor activity and cocaine discrimination in dopamine D4 receptor mutant mice. Psychopharmacology (Berl) 170: 108-114.

Khaled MA, Farid Araki K, Li B, Coen KM, Marinelli PW, Varga J et al (2010). The selective dopamine D3 receptor antagonist SB 277011-A, but not the partial agonist BP 897, blocks cue-induced reinstatement of nicotine-seeking. Int $J$ Neuropsychopharmacology 13: 181-190.

Khan ZU, Gutierrez A, Martin R, Penafiel A, Rivera A, De La Calle A (1998). Differential regional and cellular distribution of dopamine D2-like receptors: an immunocytochemical study of subtype-specific antibodies in rat and human brain. J Comp Neurol 402: 353-371.

Kotler M, Cohen H, Segman R, Gritsenko I, Nemanov L, Lerer B et al (1997). Excess dopamine D4 receptor (D4DR) exon III seven repeat allele in opioid-dependent subjects. Mol Psychiatry 2: 251-254.

Kruzich PJ, Suchland KL, Grandy DK (2004). Dopamine D4 receptor-deficient mice, congenic on the C57BL/6J background, are hypersensitive to amphetamine. Synapse 53: 131-139.

Laviolette SR, van der Kooy D (2004). The neurobiology of nicotine addiction: bridging the gap from molecules to behaviour. Nat Rev Neurosci 5: 55-65.

Le Foll B, Gallo A, Le Strat Y, Lu L, Gorwood P (2009). Genetics of dapamine receptors and drug addiction: a comprehensive review. Behav Pharmacol 20: 1-17.

Le Foll B, Goldberg SR (2004). Rimonabant, a $\mathrm{CB}_{1}$ antagonist, blocks nicotine-conditioned place preferences. Neuroreport 15: 2139-2143.

Le Foll B, Goldberg SR (2005). Ethanol does not affect discriminative-stimulus effects of nicotine in rats. Eur J Pharmacol 519: 96-102.

Le Foll B, Goldberg SR (2006). Nicotine as a typical drug of abuse in experimental animals and humans. Psychopharmacology(Berl) 184: $367-381$

Le Foll B, Justinova Z, Wertheim CE, Barnes C, Goldberg SR (2008). Topiramate does not alter nicotine or cocaine discrimination in rats. Behav Pharmacol 19: 13-20.

Le Foll B, Wertheim C, Goldberg SR (2007). High reinforcing efficacy of nicotine in non-human primates. PLOS ONE 2: e230.

Lerman C, Caporaso N, Main D, Audrain J, Boyd NR, Bowman ED et al (1998). Depression and self-medication with nicotine: the modifying influence of the dopamine D4 receptor gene. Health Psychol 17: 56-62.

Li T, Zhu ZH, Liu X, Hu X, Zhao J, Sham PC et al (2000). Association analysis of polymorphisms in the DRD4 gene and heroin abuse in Chinese subjects. Am J Med Genet 96: 616-621.

Liu X, Caggiula AR, Yee SK, Nobuta H, Poland RE, Pechnick RN (2006). Reinstatement of nicotine-seeking behavior by drugassociated stimuli after extinction in rats. Psychopharmacology (Berl) 184: 417-425.

Liu X, Jernigen C, Gharib M, Booth S, Caggiula AR, Sved AF (2010). Effects of dopamine antagonists on drug cue-induced reinstatement of nicotine-seeking behavior in rats. Behav Pharmacol 21: 153-160. 
Luciano M, Zhu G, Kirk KM, Whitfield JB, Butler R, Heath AC et al (2004). Effects of dopamine receptor D4 variation on alcohol and tobacco use and on novelty seeking: multivariate linkage and association analysis. Am J Med Genet B Neuropsychiatr Genet 124B: 113-123.

Mamiya T, Matsumura T, Ukai M (2004). Effects of L-745,870, a dopamine D4 receptor antagonist, on naloxone-induced morphine dependence in mice. Ann NY Acad Sci 1025: 424-429.

Mansvelder HD, McGehee DS (2000). Long-term potentiation of excitatory inputs to brain reward areas by nicotine. Neuron 27: 349-357.

McClernon FJ, Hutchison KE, Rose JE, Kozink RV (2007). DRD4 VNTR polymorphism is associated with transient fMRI-BOLD responses to smoking cues. Psychopharmacology (Berl) 194: 433-441.

Morisano D, Bacher I, Audrain-McGovern J, George TP (2009). Mechanisms underlying the comorbidity of tobacco use in mental health and addictive disorders. Can J Psychiatry 54: 356-367.

Mrzljak L, Bergson C, Pappy M, Huff R, Levenson R, GoldmanRakic PS (1996). Localization of dopamine D4 receptors in GABAergic neurons of the primate brain. Nature 381: 245-248.

Munafo MR, Johnstone EC (2008). Smoking status moderates the association of the dopamine D4 receptor (DRD4) gene VNTR polymorphism with selective processing of smoking-related cues. Addict Biol 13: 435-439.

Naqvi NH, Rudrauf D, Damasio H, Bechara A (2007). Damage to the insula disrupts addiction to cigarette smoking. Science 315: 531-534.

Nayak S, Cassaday HJ (2003). The novel dopamine D4 receptor agonist (PD 168,077 maleate): doses with different effects on locomotor activity are without effect in classical conditioning. Prog Neuropsychopharmacol Biol Psychiatry 27: 441-449.

Oak JN, Oldenhof J, Van Tol HH (2000). The dopamine D(4) receptor: one decade of research. Eur J Pharmacol 405: 303-327.

Palmatier MI, Evans-Martin FF, Hoffman A, Caggiula AR, Chaudhri N, Donny EC et al (2006). Dissociating the primary reinforcing and reinforcement-enhancing effects of nicotine using a rat self-administration paradigm with concurrently available drug and environmental reinforcers. Psychopharmacology (Berl) 184: 391-400.

Palmatier MI, Liu X, Matteson GL, Donny EC, Caggiula AR, Sved AF (2007a). Conditioned reinforcement in rats established with self-administered nicotine and enhanced by noncontingent nicotine. Psychopharmacology (Berl) 195: 235-243.

Palmatier MI, Matteson GL, Black JJ, Liu X, Caggiula AR, Craven L et al (2007b). The reinforcement enhancing effects of nicotine depend on the incentive value of non-drug reinforcers and increase with repeated drug injections. Drug Alcohol Depend 89: 52-59.

Patel S, Freedman S, Chapman KL, Emms F, Fletcher AE, Knowles $M$ et al (1997). Biological profile of L-745,870, a selective antagonist with high affinity for the dopamine D4 receptor. J Pharmacol Exp Ther 283: 636-647.

Picciotto MR (2003). Nicotine as a modulator of behavior: beyond the inverted U. Trends Pharmacol Sci 24: 493-499.

Pidoplichko VI, DeBiasi M, Williams JT, Dani JA (1997). Nicotine activates and desensitizes midbrain dopamine neurons. Nature 390: 401-404.

Pierce RC, Kumaresan V (2006). The mesolimbic dopamine system: the final common pathway for the reinforcing effect of drugs of abuse? Neurosci Biobehav Rev 30: 215-238.

Risner ME, Goldberg SR (1983). A comparison of nicotine and cocaine self-administration in the dog: fixed-ratio and progressive-ratio schedules of intravenous drug infusion. J Pharmacol Exp Ther 224: 319-326.
Rose JE, Corrigall WA (1997). Nicotine self-administration in animals and humans: similarities and differences. Psychopharmacology (Berl) 130: 28-40.

Ross JT, Corrigall WA, Heidbreder CA, LeSage MG (2007). Effects of the selective dopamine D3 receptor antagonist SB$277011 \mathrm{~A}$ on the reinforcing effects of nicotine as measured by a progressive-ratio schedule in rats. Eur J Pharmacol 559: 173-179.

Rubinstein M, Phillips TJ, Bunzow JR, Falzone TL, Dziewczapolski $\mathrm{G}$, Zhang $\mathrm{G}$ et al (1997). Mice lacking dopamine D4 receptors are supersensitive to ethanol, cocaine, and methamphetamine. Cell 90: 991-1001.

Schmidt HD, Pierce RC (2006). Cooperative activation of D1-like and D2-like dopamine receptors in the nucleus accumbens shell is required for the reinstatement of cocaine-seeking behavior in the rat. Neuroscience 142: 451-461.

Self DW (2004). Regulation of drug-taking and -seeking behaviors by neuroadaptations in the mesolimbic dopamine system. Neuropharmacology 47(Suppl 1): 242-255.

Shaham Y, Adamson LK, Grocki S, Corrigall WA (1997). Reinstatement and spontaneous recovery of nicotine seeking in rats. Psychopharmacology (Berl) 130: 396-403.

Shao C, Li Y, Jiang K, Zhang D, Xu Y, Lin L et al (2006). Dopamine D4 receptor polymorphism modulates cue-elicited heroin craving in Chinese. Psychopharmacology (Berl) 186: 185-190.

Sofuoglu M, Yoo S, Hill KP, Mooney M (2007). Self-administration of intravenous nicotine in male and female cigarette smokers. Neuropsychopharmacology 33: 715-720.

Svingos AL, Periasamy S, Pickel VM (2000). Presynaptic dopamine $\mathrm{D}(4)$ receptor localization in the rat nucleus accumbens shell. Synapse 36: 222-232.

Thanos PK, Habibi R, Michaelides M, Patel UB, Suchland K, Anderson BJ et al (2010). Dopamine D4 receptor (D4R) deletion in mice does not affect operant responding for food or cocaine. Behav Brain Res 207: 508-511.

Thomas MJ, Kalivas PW, Shaham Y (2008). Neuroplasticity in the mesolimbic dopamine system and cocaine addiction. $\mathrm{Br} J$ Pharmacol 154: 327-342.

Thomas TC, Kruzich PJ, Joyce BM, Gash CR, Suchland K, Surgener SP et al (2007). Dopamine D4 receptor knockout mice exhibit neurochemical changes consistent with decreased dopamine release. J Neurosci Methods 166: 306-314.

Ukai M, Mitsunaga H (2005). Involvement of dopamine D3 and D4 receptors in the discriminative stimulus properties of cocaine in the rat. Methods Find Exp Clin Pharmacol 27: 645-649.

Wang X, Zhong P, Gu Z, Yan Z (2003). Regulation of NMDA receptors by dopamine D4 signaling in prefrontal cortex. J Neurosci 23: 9852-9861.

Wang X, Zhong P, Yan Z (2002). Dopamine D4 receptors modulate GABAergic signaling in pyramidal neurons of prefrontal cortex. J Neurosci 22: 9185-9193.

Wise RA (2004). Dopamine, learning and motivation. Nat Rev Neurosci 5: 483-494.

Woolley ML, Waters KA, Reavill C, Bull S, Lacroix LP, Martyn AJ et al (2008). Selective dopamine D4 receptor agonist (A-412997) improves cognitive performance and stimulates motor activity without influencing reward-related behaviour in rat. Behav Pharmacol 19: 765-776.

Yan Y, Mizuno T, Nitta A, Yamada K, Nabeshima T (2004). Nefiracetam attenuates methamphetamine-induced discriminative stimulus effects in rats. Ann NY Acad Sci 1025: 274-278.

Yan Y, Nitta A, Mizuno T, Nakajima A, Yamada K, Nabeshima T (2006). Discriminative-stimulus effects of methamphetamine and morphine in rats are attenuated by cAMP-related compounds. Behav Brain Res 173: 39-46.

Ziedonis D, Hitsman B, Beckham JC, Zvolensky M, Adler LE, Audrain-McGovern J et al (2008). Tobacco use and cessation in psychiatric disorders: National Institute of Mental Health report. Nicotine Tob Res 10: 1691-1715. 